\title{
Brand Activation: A Review on Conceptual and Practice Perspectives
}

\author{
Ravindra Dissanayake ${ }^{1} \&$ Nisal Gunawardane ${ }^{1}$ \\ ${ }^{1}$ Department of Marketing Management, Faculty of Commerce and Management Studies, University of \\ Kelaniya, Sri Lanka \\ Correspondence: Ravindra Dissanayake. Tel: 94-07-1683-3615. E-mail: dmravidissa@gmail.com/ravi@kln.ac.lk
}

Received: May 4, 2018 Accepted: June 29, $2018 \quad$ Online Published: July 27, 2018

doi:10.5539/ass.v14n8p37 URL: https://doi.org/10.5539/ass.v14n8p37

\begin{abstract}
Brand activations is claimed as a notion found within experiential and behavioral contexts of branding. There are empirical studies claim brand activation is inline within the scope of event marketing. As per some arguments, brand activation finds itself imprecise foundation to explain its theoretical foundation. Supportively, studies are highlighting theoretical and empirical scant in examining influence of brand activation though practices are extendedly found. Alongside, this paper attempts to review the notion of brand activation in relation to empirical explanations, cases and its presence in different scenarios. Authors followed literature review as the main research strategy whilst specific attention was made to Asian market context in explaining cases and practices. Accordingly, paper investigates the concept of brand activation in relations to different scopes including branding, consumer behavior whilst digital or viral marketing platforms are also referred. Authors discuss the influence and association of brand activation with reference to different scenarios and cases directing future research requirements. Paper concludes research propositions in line with the empirical justifications encouraging future research priorities.
\end{abstract}

Keywords: Asian market, brand activation, consumer behavior, experiential marketing, event marketing

\section{Introduction}

Creating brand equity is an integrated process of designing and executing strategies where marketing communication bridges brand and target customers (Aaker, 1996). Being an integral part in holistic branding strategy, brand activation clears a ground to link brands to consumers via feel, sense and relate perspectives (Hussain, 2013). Brand activation ultimately connects brand into customer experiences via a big idea. Alongside, brand activation is viewed as a tool that connects brand and consumers whilst measuring its impact is considered as a critically important matter (Choi, 2008). Marketing communication also bridges such link between brand purpose and consumer expectations. In overall, consumer satisfaction and customer retention shine as main concerns in customer relationship marketing that eventually links brands into consumer life. Customer relationship marketing concerns with attracting, developing and retaining customer with business entity (Berry \& Parasuraman,2013; Morgan \& Hunt, 1994). In services, service quality is having a direct impact on customer satisfaction and customer relationship (Velnampy \& Sivesan, 2012). Brand needs such connective stimulus to create relationship or brand bond with the respective target customers. As per Jackson (2013), events can be used as a tool in order to develop consumer relationship for a better understanding among consumer and the business entity and event is one of the main components comes under the umbrella of brand activation (Marist, Yuliati \& Najib, 2014).Brand Activation arose in the field of Marketing and Communication as a mechanism of consumer experience enhancer (Liembawati, Dharmayanthi, Karina, Pemasaran, Petra, \& Siwalannkerto, 2014). According to Alberts (2009), activation is a process of activating consumers which enhance consumer interest, trial and loyalty. Further it mentioned activations shift the core focus to marketing which stimulates the consumer buying process (Alberts, 2009). Brand activation resulted by enhancing the bond with consumer creating a platform by allowing consumer to experience the brand in an interactive manner (Saeed, Author, Zameer, \& Ahmad, 2015). Further, Saeed et al. (2015) said brand activation is a marketing interaction created between consumer and the brand where consumer understands the brand in a better way resulting perceiving brand as a component of their lives. Effective brand activation influences consumer to engage with brands in which said collaboration will drive brand sales volume and create customer loyalty (Gendron, 2017). Supportively, brand activation is also referred as a strategic and tactical face that enables customers experiencing brand engagement (Saeed et al., 2015). Brand activation is not a mean of activate the brand itself yet it's a 
mechanism which activates the customer, the final goal is to create an active customer one who is primed for activation (Mckay \& Brown, 2016). Meanwhile, Saeed et al. (2015) argue that brand activation is a mean of activate the brand which induces a connection between brand and the consumer. However brand activation is claimed as a concept that needs more theoretical and empirical explanation as per the arguments found in empirical works held in different fields (Choi, 2008; Malik, Sudhakar, \& Dutta, 2017).

Alongside, one of the main problems found in research and practice perspectives is measuring the impact of brand activation as it links to various avenues of outcome (Ghosal, 2010). In identifying the measurements for brand activation, it reveals brand activation can be measured by using of sales support or effectiveness of new product development (Morel, Preisler, \& Nyström, 2002); whilst some argue brand activation can only be measured through awareness and visibility rather sales support (Saeed et al., 2015). Effectiveness of brand activation needs to be measured for a rational justifications, but yet to be explored in terms of measurements (Choi, 2008; Soderman \& Dolles, 2015). Likewise, brand activation alarms extended investigations in empirically examining its impact on brands and behavioral results. However, it still finds issues on its conceptual content as a strategy or tactic. Thus, it clears brand activation opens avenues to argue on its content, involvement and effectiveness in the sphere of branding and consumer behavioral perspectives.

\subsection{Purpose of the Study}

Brand activation is referred as operational content in brand strategy whilst some argue it itself a strategy linked with management contents of brand promotions (Seno \& Lukas, 2007). Meanwhile, brand activation is claimed as a context which is not being properly framed as a theory or constructive model with measurements in general (Choi, 2008; Saeed et al., 2015). However, it denotes as a significant practice as per the intensity of use in brand building strategies result consumer engagements (Saeed et al., 2015). Some argued brand activation is a notable area claiming empirical investigations to rationalize its strategic use in celebrity endorsements (Dissanayake, 2015). The significance of brand activation has been referred in relation to many consumer behavioral contexts though enough empirical examinations are yet to be found scant even within digital context (Choi, 2008; Malik, et al., 2017). Thus, we argue brand activation needs to be empirically tested in different brand-related contexts to unveil its influence on consumers to engage with respective brands. Therefore, this paper attempts to investigate how brand activation has been found in empirical studies connected to behavioral outcomes and brand performance - related outcomes. Additionally, this paper contributes to existing knowledge as a conceptual review to synthesize how brand activation is researched and claimed in future research directions. Authors present cases alongside the empirical contributions to signify how brand activation is intensively referred in behavioral studies whilst industry practices are also highlighted.

\subsection{Methodology}

This paper fallows deductive approach in which arguments and explanations are mainly supported by empirical evidences and associated theoretical contents. Alongside, authors reviewed journal articles and industry publications to review the concepts and applications pertained to brand activation. Accordingly, literature review was employed as the main research tool. Paper attempted to discuss cases found within the application of brand activations to import practice related insights for the readers. Authors highlight some industry specific issues and case evidences whilst specific concern is made on Sri Lankan industry practices. Paper is organized as a concept paper whilst arguments were empirically supported. Finally, authors discuss and conclude the paper by postulating future research directions in line with the synthesized discussions.

\section{Theoretical Review on Brand Activation}

Brand Activation is not a theory yet it is a mean of evaluation in brands (Morel et al., 2002). Brand experience was identified as one essential component of brand activation which leads to consumer brand satisfaction and brand trust (Marist et al., 2014). The Persuasive Communication Theory of Ajzen (1992) suggests if a marketing promotional tool is persuasive in nature, it will make a room of creating trust and loyalty. Brand trust is the consumer's average belief about a brand to satisfy the expected outcomes from the brand itself (Chaudhuri \& Hoibrook, 2001); and it raises within the notion of brand evaluation (Dissanayake \& Ismail, 2015). Supportively, brand activation is explained within persuasive marketing communication referring it makes customers influenced to respond marketing message reinforced by the content of respective brand activation programs (Marist et al., 2014; Mu, 2017). Thus, future studies may work on persuasive communication theory to frame empirical studies in examine how brand activations result trust and loyalty. Further, the trust in brand is capable of creating consumer loyalty which enhances the relationship marketing aspect in between the consumer and the brand (. Meanwhile, brand trust has been examined as a context of brand evaluations resulted by stimulated brand communications including celebrity endorsements as one of them (Dissanayake, 2015). Supportively, 
brand activation is referred as a management-based factor within the scope of effectiveness of celebrity endorsement (Seno \& Lukas, 2007). Thus, brand activation seems connected to many marketing communication related contexts including celebrity involvement, events, experiential programs and relationship building activities.

It refers that brand activation is a persuasive marketing promotional tool which could enhance consumer trust and loyalty (Marist et al., 2014; Liembawati et al., 2014; Saeed et al., 2015). According to Saeed et al. (2015), brand activation could be mainly classified in to five main perspectives as Discovery, at this level the marketers needs to identify the brand and its attributes, who the customer is and what their needs are. The second phase is Strategic Development, which connects to creative and persuasive communication referring how brand message could export to target group by activating the brand. Next Creative Development indicates the importance of creative ways on execution focusing higher level of consumer involvements. The fourth phase is the Delivery point referring how the planned brand activation offers to a target group. Finally, the Evaluation is the concluding point where it evaluates the total effectiveness of respective brand activation program. This is where the arguments find as brand stimulation methods usually result both qualitative and quantitative outcomes. For instance, celebrities who involve in brand activations as a management-based factor result brand evaluations and brand-related behaviors (Dissanayake \& Ismail, 2015; Hung, 2014; Seno \& Lukas, 2007). Thus, theoretical and empirical investigations yet need to address in examining impact of brand activations on overall behavioral and cognitive outcomes.

As cited by Attri (2013), brand activation is in line with the process specified in AICDA Model which grabs attention interest, consideration, desire and action. Brand activation linked on consumer nostalgia is common strategy in western countries to solve problems associated with aging brands in stimulating consumer nostalgia leads to a purchases decision (Mu, 2017). Brand activation is used to increase sales of a dip in demand product within a short time period denoting sales promotions run with a brand activation (Saeed et al., 2015). Thus, it clears brand activation acts as an intensifier of brand related outcomes connected to different brand building stimulus.

\section{Empirical Review on Influence of Brand Activation in Different Scenarios}

Brand activation should be capable of triggering a change in consumer behavior and produce a clear and measurable outcome rather simply impact on creating awareness, consumer loyalty and general interest towards the brand (Mckay \& Brown, 2016). Brand activation influences such brand-related results via a flavor of experiential marketing (Attri, 2013). According to Brakus, Schmitt and Zarantonello (2009), experiential marketing is resulted in creating consumer trust which leads to develop consumer attitudinal and behavioral loyalty. The scenario of brand experience is a subjective or internal consumer response; and behavioral responses are evoked by brand-related stimuli including brand's design, identity, packing, communication and environment (Brakus et al., 2009). Brand experiences do not occur only after consumption, yet this can be occurred whenever there is a direct or indirect interaction with the brand (Şahin, Zehir, \& Kitapçi, 2011). Brand activation is a consumer experience creator which influences consumer sensory appeal. Brand activation is a platform which provides a positive point for both consumer and the company. Alongside, it could conclude that brand experience is an inseparable component of brand activation (Liembawati et al., 2014).

Activation is simply attributing a sponsorship into an action (Soderman \& Dolles, 2015); and sponsorship opens an access to the exploitable commercial potential associated with that property (Cornwell et al., 2013). Further, brand activation aims to improve the communication to consumers in a better way and supports increasing sales whilst assisting in establishing a position (Liembawati et al., 2014). Brands do invest on activations based on the product, its attributes and revenue. Additionally, advertising is considered to be one of the main essential components of activation for its success (Soderman, 2015). The scenario of brand activation has been extendedly argued within the context of celebrity involvements in influencing brand evaluation results brand-relationship behavior. Some argue brand activation is a matter of how sponsored-brands manage celebrity endorsement strategies alongside the source-based factors (Dissanayake \& Ismail, 2015; Hung, 2014; Seno \& Lukas, 2007). The issues are found how management-based factors could shape the complexities may occur when multiple endorsements dominate the celebrity endorsement practices in a given market. For instance, service sector of Sri Lanka has been claimed as such a context whereby multiplicity occurs challenging overall effectiveness of celebrity endorsements whilst brand activation is claimed as a solution to avoid possible negative impacts (Dissanayake \& Ismail, 2015). The strategic role of management-based factors of celebrity endorsements including media management and brand activation could mitigate such negative influences on brand evaluation and brand relationship behaviors resulted by multiplicity. Scenarios are found using popular celebrities in brand activations supported by integrated advertising campaigns. But, logical examination is needed to evaluate their 
effectiveness in line with how consumers psychologically admire or worship respective celebrity character (Dissanayake, 2015; Hung, 2014). Thus, brand activation involved by celebrities is a specific context demands systematic empirical investigations. Alongside, future researches are encouraged to examine how behavioral outcomes are resulted by multiplicity and brand activations within different product and market contexts (Hung, 2014).

In addition, digital activation is one of the prominent scenarios results reaching a larger target audience compared to traditional activations. But, there is a lack of evidence of empirical studies on digital activations and its outcome (Choi, 2008). Social media is a strategic option for such experiential brand communications to influence brand-related responses and viral effects. Meanwhile, it refers online as one of the highly recommended means to share stimulus reducing gap between consumer and the brand (Mckay \& Brown, 2016), and digital brand activations play a significant impact within viral marketing context (Choi, 2008). As foresaid, studies need to investigate how viral or online brand activations effectively influence brand-related responses.

\section{Case Reviews on Brand Activation}

Most of global brands use brand activation as a communication mechanism over adverting owing to its immediate and interactive influence. Usually, attendees of a brand activation program can be pre-defined and controlled by the brand activator prior executing the program. As per Association of National Advertisers (ANA), brand activation uses six avenues which connect and interacts with the consumer to bring life to a brand namely promotion marketing, experiential marketing, retailer marketing, relationship marketing, content marketing and influencer marketing. Supportively, Coca-Cola conducted a brand activations for Beijing Summer Olympic in 2008 with the help of touch rally program and finally it became one of the effective Olympic activations for Coke resulted generating a comprehensive data base for coke interactive marketing programs (Choi, 2008; Soderman, \& Dolles, 2015). Brand activations of Sochi Olympic games and the Russian National Hockey League of Carlsberg resulted growth of the brand volume in sales by 2012 (Carlsberg, 2013). The results showed that brand activation as a mean of marketing promotion that generates consumer brand awareness leading to sales volume growth. Celebrities in brand activation for services including telecommunication and insurance sector of Sri Lanka had been figured out as another practice-related evidence of brand activations (Dissanayake, 2015). Brand activations do create consumer experience (Marist et al., 2014). Unilever uses brand activation as one of the main consumer experience creators for the brand "Lifebuoy" via a program activated as a hygiene promotion activation educating consumers about product usage and benefits (Unilever, 2008). Further, experiential based brand activation resulted in forming a brand community for Indonesian based wheat flour manufacturer "Bogasari" promoted its products through event marketing activities (Liembawati et al., 2014). Thus, it seems brand activation is found as an integral component in event marketing perspective across the industries.

According to Saeed et al. (2015), fast moving consumer goods (FMCG) brands are supported by brand activations providing a platform for potential and existing consumers to experience the product compared to service brands. There are certain products which only should use activations in order to promote the product, specially the products that customers need to experience before they buy the product including automobiles and cellphone brands (Johnson, 2008). Further Johnson (2008) reveals there are products that should have activation plus product sampling in order to have an effective outcome including beverage brands, precooked brands and fresh foods which need to have demonstration as a form of activation. Today, consumers are not that influenced by push strategy and above-the-line (ATL) marketing gimmicks, where they look for more personalized connections which can bring brand sensory touch points which brand activation usually creates (Mckay \& Brown, 2016). Brand activation is forming a level where consumer becomes an "activist" who literally makes or breaks a brand being influenced by others and among them (Mckay \& Brown, 2016). When brand activation and self-activation are co-occurred, it may create person's identity prominence at a higher level (Park, MacInnis, Priester, Eisingerich, \& Iacobucci, 2010). Thus, it denotes brand activation results and intensifies brand relationship behaviors and evaluations. There are cases found brands use activations as an effective tool to make brand engagements and influence people trusting to buy health care products. As cited by Attri (2013), Dettol and Lifebuoy largely apply brand activation in India to connect consumers and decision makers via actively-engaged events and experiential marketing campaigns. We also highlight Sri Lankan cases where Lifebuoy, Signal Toothpaste and Astra of Unilever extendedly implement such activations in schools and community gathering occasions. However, important matter is to integrate such brand activation programs with the promotion mix to get an extended mileage. It will result higher brand recall and positioned impact provided brand activations are backed by integrated promotion mix. Some activations are limited for a time or session and it does not include post-event connection with customers. This may weaken the effectiveness of brand 
activations towards brand evaluations and brand -related behaviors. Brand activation should lead to mitigate the gap between brand and consumer (Mckay \& Brown, 2016). Thus, extended connectivity of brand and consumers is that important in brand activations. Authors highlight some brand activation programs took place in Sri Lankan mobile communication services in the forms of competitions and game entertainments. The main purpose of those events was to associate speed and convenience as brand benefits to motivate customers try and experience data packages. But, argument is how far it extends to brand relationship behaviors via integrated and associated brand communication strategies. Consumers link to brand relationships via social relationships (Aggarwal 2004). Thus, extended communication is a must to assure consumers to get bonded with activated brands. Celebrities are used in active promotions for such relationship bonds for a better brand evaluation like brand love and brand trust (Koththagoda \& Dissanayake, 2017). We propose integration of off-line activations and post-event memory sharing communications via online or viral forms could intensify motivation with brand experience. Activations are mainly expected to be enablers of brand experiences (Marist et al., 2014). Thus, we denote the importance of brand activations as an integrated promotional tool that enables consumers to hold brand-related information and brand experiencing memory in modeling engagements with the brand. The communication niche of a brand activation event should be in line with the unique value proposition (USP) positioned in connection to the respective brand. In brief, "Big Idea" of branding campaigns needs to be experienced through brand activations for a better gain.

\section{Conclusion and Further Research Directions}

Brand activation is not a theory, yet it's a natural step of evaluation of brand (Morel et al., 2002). Brand activation is a branch comes under relationship marketing which enhances consumer retention (Jackson, 2013). Several researchers indicated that brand activation is a field which is yet to explore within different product contexts. Brand activation is a novice research section which is a probable area to study with reference to brand-related behaviors and evaluations (Attri, 2013; Gunawardane, Dissanayake, \& Munasinghe, 2016; Soderman \& Dolles, 2015). The main issue found with brand activation is the absence of holistic measurements indicators to be used in behavioral studies. Thus, brand activation measurements may be developed by associating the notions of activity content, activity management content and experiential content. Likewise, this paper attempted to highlight how empirical studies reveal brand activation in relation to brand evaluation and relationship spheres whilst denoting future research propositions including the scant of measurement scales for brand activation. Paper reveals how brand activation results different brand-related and consumer behavioral outcomes whilst highlighting cases found in different product scopes. Finally, authors highlight the empirical gaps found in present research spheres to examine how brand activation results brand evaluations and brand-related behaviors. For instance, celebrity engagements in brand activation as a management-based factor demands further investigations over its traditional use of endorsed-advertisings (Dissanayake, 2015; Hung, 2014; Malik et al., 2017). Thus, future research works are encouraged to investigate how brand activations could result consumer behavioral responses that eventually influence brand performances within different product scopes. We suggest persuasive communication theory (Ajzen, 1992) as one of the theoretical rationales for conceptualizing empirical studies on brand activations. Accordingly, brand trust and brand loyalty could be examined as outcomes of persuasive communications including brand activations. Conclusively, new studies may focus how brand activations results in services sector, FMCG, industrial marketing and consumer durable sector as consumer engagements are differently framed across the product scopes. A specific research interest is admired to examine brand activations in viral forms as per the intensity of practice and challenges reported.

\section{References}

Aaker, D. A. (1996). Building Strong Brands. New York: Free Press.

Ajzen, I. (1992). Persuasive Communication Theory in Social Psychology: A Historical Perspective. Sagamore Publishing.

Aggarwal, P. (2004). "The Effects of Brand Relationship Norms on Consumer Attitudes and Behavior," Journal of Consumer Research, 31 (June), 87-101

Alberts, P. G. (2009). What is Brand Activation? Retrieved from http://brandactivation.com/theory

Attri, R. (2013). Brand Activation: The Mantra for Success in Times to Come, Facing Challenges in the Era of Globalization. New Delhi: Excellent Publishing House.

Berry, B. L. L., \& Parasuraman, A. (2013). Marketing Services: Competing Through Quality. Journal of Marketing, 56(2), 132-134.

Brakus, J. J., Schmitt, B. H., \& Zarantonello, L. (2009). Brand Experience: What Is It? How Is It Measured? 
Does It Affect Loyalty?. Journal of Marketing, 73(5), 52-68. https://doi.org/10.1509/jmkg.73.3.52

Carlsberg, (2013). Annual Report Management review Financial. Copenhagen.

Chaudhuri, A., \& Hoibrook, M. B. (2001). The Chain of Effects from Brand Trust and Brand Affect to Brand Performance: The role of Brand Loyalty. Journal of Marketing, 65(2), 81-93. https://doi.org/10.1509/jmkg.65.2.81.18255

Choi, J. A. (2008). Coca-Cola China's Virtual Olympic Torch Relay programme at the 2008 Beijing Olympic Games: Adding interactivity to a traditional offline Olympic activation. International Journal of Sports Marketing and Sponsorship, 9(4), 246-255. https://doi/pdfplus/10.1108/IJSMS-09-04-2008-B004

Cornwell, T. B., Weeks, C. S., \& Roy, D. P. (2013). Sponsorship-Linked Marketing: Opening the Black box. Journal of Advertising, 34(2), 21-42. https://doi.org/10.1080/00913367.2005.10639194

Dissanayake, D. M. R. (2015). Factors Determine the Customer-Celebrity Relationship towards Perceived Celebrity Endorsements: Propositions to Hypothesize Future Studies in Sri Lankan Services Sector. Sri Lanka Journal of Marketing, 1(2), 1-19.

Dissanayake, D. M. R., \& Ismail. (2015). Relationship between Celebrity Endorsement and Brand Attitude: With Reference to Financial Services Sector Brands in Sri Lanka. Conference Proceedings, International Conference on Business \& Information, 1-22.

Gendron, M. (2017). From Public Relations to Brand Activation: Integrating today's Communications Tools to Move Business Forward. Journal of Organizational Behavior, 28(3), 303-325. https://doi.org/10.1002/joe.21775

Gunawardane, N., Munasinghe, A., \& Dissanayake, D. M. R. (2016). Relationship between Perceived Brand Equity and Purchase Intention of Life Insurance Brands in Sri Lanka: A Concept Paper. International Journal of Business and Management Invention, 5(12), 2319-8028.

Hung, K. (2014). Why Celebrity Sells: A Dual Entertainment Path Model of Brand Endorsement. Journal of Advertising, 43(2), 155-166. https://doi.org/10.1080/00913367.2013.838720

Hussain, A. (2013). Brand Activation, Bringing the spirit of Brand to Life. Retrieved from http://www.slideshare.net/aasifhussain/brand-activation

Jackson, N. (2013). Promoting and Marketing Events -Theory and practice. Taylor \& Francis Group; Abingdon: Routledge.

Johnson, C. (2008). Event Marketing or Product Sampling? Journal of Consumer Marketing, 25(5), 269-271. https://doi/full/10.1108/07363760810890499

Koththagoda, K. C., \& Dissanayake, D. M. R. (2017). Perceived effectiveness of celebrity endowment on perceived brand evaluation in the scope of services sector: A review paper. International Journal of Business and Management Review, 5(7), 9-21.

Liembawati, Y., Dharmayanti, D., Si, M., Karina, R., Pemasaran, P. M., Petra, U. K., \& Siwalankerto, J. (2014). Analisa Pengaruh Brand Activation Terhadap Pembentukan Brand Community Pada Pt Ism Bogasari Flour Mills. Jurnal Manajemen Pemasaran Petra, 2(1), 1-15.

Malik, A., Sudhakar, B. D., \& Dutta, D. S. (2017). Management-Based Factors of Sports Celebrity Endorsement and Effect on Brand Image. IIM Kozhikode Society \& Management Review, 7(1) 1-13. https://doi:10.1177/2277975217733882

Marist, A. I., Yuliati, L. N., \& Najib, M. (2014). The Role of Event in Building Brand Satisfaction, Trust and Loyalty of Isotonic Drink. International Journal of Marketing Studies, 6(6), 57-66. https://doi.org/10.5539/ijms.v6n6p57

Mckay, A., \& Brown, G. (2016, May). Retail's Future Lies in Activating Customers, Not Brands. Retail World, 54-55.

Morel, P., Preisler, P., \& Nyström, A. (2002). Brand activation. Starsky Insight. Retrieved from http://easylink.terki.no/index.php/content/content/download/159/699/version/file/13BrandActivation.pdf

Morgan, R. M., \& Hunt, S. D. (1994). Theory of Relationship Marketing. Journal of Marketing, 58(3), 20-38. http://dx.doi.org/10.2307/1252308

$\mathrm{Mu}$, J. (2017). The Study on Activation Strategy of Time-honored Brand. In MATEC Web of Conferences, 100(1), $1-5$. 
Park, W. C., MacInnis, D. J., Priester, J., Eisingerich, \& Iacobucci, D. (2010). Brand Attachment and Brand Attitude Strength: Conceptual and Empirical Differentiation of Two Critical Brand Equity Drivers. Journal of Marketing, 74(6), 1-17. https://doi.org/10.1509/jmkg.74.6.1

Saeed, R., Author, C., Zameer, H., \& Ahmad, I. (2015). Brand Activation: A Theoretical Perspective. Journal of Marketing and Consumer Research, 13(1), 94-99.

Şahin, A., Zehir, C., \& Kitapçi, H. (2011). The effects of Brand Experiences, Trust and Satisfaction on Building Brand Loyalty; an Empirical Research on Global Brands. In Procedia - Social and Behavioral Sciences, 24(1), 1288-1301. https://doi.org/10.1016/j.sbspro.2011.09.143

Seno, D., \& Lukas, B. A. (2007). The Equity Effect of Product Endorsement by Celebrities: A Conceptual Framework from a Co-branding Perspective. European Journal of Marketing, 41(1), 121-134. https://doi.org/10.1108/03090560710718148

Soderman, S., \& Dolles, H. (2015). Unlocking Advertising, Activation and Sponsorship in an Emerging Market. Sport, Business and Management: An International Journal, 5(5), 472-492. https://doi.org/10.1108/SBM-09-2015-0030

Unilever Sri Lanka. (2008). Towards universal hand washing with soap. Unilever- Lifebuoy Marketing. Colombo.

Velnampy, T., \& Sivesan, S. (2012). Customer Relationship Marketing and Customer Satisfaction: A Study on Mobile Service Providing Companies in Sri Lanka. Global Journal of Business \& Management Research, 12(18), 1-7.

\section{Copyrights}

Copyright for this article is retained by the author(s), with first publication rights granted to the journal.

This is an open-access article distributed under the terms and conditions of the Creative Commons Attribution license (http://creativecommons.org/licenses/by/4.0/). 